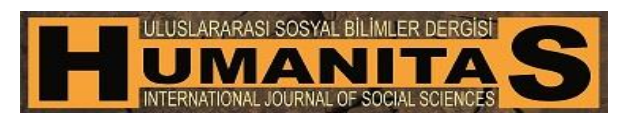

$\begin{array}{ll}\text { Humanitas, 2017; 5(9): 155-171 } & \text { http://humanitas.nku.edu.tr } \\ \text { ISSN: } 2147-088 X & \text { DOI: } \underline{10.20304 / \text { humanitas.318508 }}\end{array}$

Araştırma-İnceleme

\title{
STRUCTURALIST PARADIGM AND MUSIC
}

\section{Gönenç HONGUR ${ }^{1}$}

\begin{abstract}
Structuralist thought has had an immense influence on scholars from various disciplines including music studies since the early years of the twentieth century. The influence of Saussure's revolutionary ideas incorporating synchronic approaches into the study of language was extremely powerful. Anthropological studies share almost the same background with linguistics in terms of focusing on more scientific basis. Developments beginning from the early nineteenth century mark anthropology's attempts to distinguish itself as a scientific field. Music, in a similar fashion, had always been close to language since both considered a communication system and had endeavoured to differentiate its studies from those of other sciences for a long time, seemed more than ready for its own revolution. Ethnomusicology, the study of social and cultural aspects of music, has also had a strong relationships with anthropology on which structuralism has made its strongest impact. This article traces structuralist principles and theories shaped by linguistics and anthropology that their methodologies and approaches have provided a great support for the underpinning of musical structuralism, employed particularly in music analysis, musicology, and ethnomusicology. Regardless of criticisms structuralist approaches receive, any musical work and its analysis either its cultural or musical context would be considered incomplete without the consideration structural methods.
\end{abstract}

Keywords: Structuralism, Music Analysis, Musicology, Ethnomusicology.

\section{YAPISALCI PARADIGMA VE MÜZIK}

Öz: Yapısalcı düşünce yirminci yüzyılın başlarından beri müzik incelemeleri dahil farklı disiplinlerden bir çok bilim insanı üzerinde geniş etki yapmaktadır. Saussure'ninsenkronik yaklaşımları dil incelemelerine dahil eden devrim niteliğindeki fikirleri daha bilimsel bir temele odaklanma açısından dilbilimle neredeyse aynı zemini paylaşan antropolojinin ve dil gibi bir iletişim sistemi olarak kabul edilen müziğinbenzer şekilde uzun zamandır kendi incelemelerini diğer bilimsel incelemelerden farklılaştıracak bilimsel devrime

${ }^{1}$ Yrd. Doç. Dr., Yüzüncü Yıl Üniversitesi, Türk Müziği Devlet Konservatuarı, Geleneksel Türk Müziği Bölümü. gonenchongur@yyu.edu.tr 
hazırlanmalarınıkolaylaştırmada son derece etkili oldu. Yine müziğin sosyal ve kültürel yönlerini inceleyen ve müzik antropolojisi ya da müzik etnografyası olarak etnomüzikoloji aynı zamanda yapısalcılığın üzerinde güçlü etki yaptığı antropolojiyle güçlü ilișkilere sahiptir. Özellikle etnomüzikolog John Blacking tarafindan bütünsel bir metot olarak geliştirilen "Kültürel Analiz" yaklaşımı müziği kültür, besteci veya janrfarklarını ortadan kaldıracak şekildeaçıklamaya çalışmaktadır. Ayrıca etnomüzikolog Steven Feld'in "Etnomüzikolojide Dilbilim Modelleri" yöntemi çok sayıda geniş kapsamlı yapısalcı değerlendirme ve analiz teşebbüsüne kayda değer bir kaynak sağlamaktadır. Bu makale metodolojileri ve yaklaşımlarıyla özellikle müzik analizi, müzikoloji ve etnomüzikolojide kullanılan müzik yapısalcılığının zemininin kurulmasına önemli destek sağlayan yapısalcı prensip ve teorilerin dilbilim ve antropolojiyi biçimlendirme sürecininizini sürmekte ve eleştirilere rağmen yapısalcı yaklaşımların müzik pratikleriyle kurulan anlamlar dünyasını yorumlamadaki etkinliğini veherhangi bir müzik eserinin kültürel veya müzikal bağlamda analizinin yapısalcı metotlar olmaksızın eksik kalacağının tespitini yapmayı amaçlamaktadır.

Anahtar Sözcükler: Yapısalcılık, Müzik Analizi, Müzikoloji, Etnomüzikoloji.

\section{Introduction}

Dating from the early years of the twentieth century, structuralist thought has had a wide appeal amongmany foremost philosophers, sociologists, psychoanalysts, literary critics, linguists, social theorists, anthropologistsand it has developed into an intellectual movement and, as the English sociologist Michael Lane describes, "a method whose scope includes all human and social phenomena, no matter what their form, thus embracing not only the social sciences proper ... but also the humanities ... and the fine arts" (1970,p. 13). According to Lane, "music, too, in so far as any composition may be expressed in terms of operations and relations, shares this characteristic of possessing structure" (1970, p. 14). Naturally, the forgoing descriptionsof Michael Lane would not be sufficient for us to comprehend the structuralism per se.Instead theyseem to be seeking to create an image of structural mechanism in our minds rather than reveal the intricacyof it.Therefore, before discussing in what manner structuralisttheorieshave been adapted to the study of music, it is helpful to acquire an overview of what the origins of the term "structuralism" and exploitation of its tenets in other scientific fields are. Two of these scientific fields-Linguistics, Anthropology-are particular interests of this paper in that their methodologiesand structuralist approaches have provided a great support for the underpinning of musical structuralism.

Neither a general review of the implementation of structuralist principles and theories nor a criticism of any portion of it is the primary objective of this paper. However, it is quite likely to employ both methods explicitly or implicitly in order to shed light on the inquiry into the conceptualizing the theories and ideas of structuralism in music theory and analysis, musicology and ethnomusicology. 


\section{Foundations of Structuralism}

It willalways remain as a lovely enigmawhether the students, who took courses delivered by the Swiss linguist Ferdinand de Saussure at the University of Geneva between 1906 and 1911, foresaw their course notes would be the foundation of one of the most significant intellectual movements of the twentieth century. However, when Saussure's lectures, based on these notes,compiled and published posthumously as Course in General Linguistics by his colleagues in 1916, many intellectuals must have foreseen it would "mark a wider movement of thought in the humanities and social sciences, characterized by the application of scientific rigor to areas that were accustomed to less stringent methodology" (Williams, 2001, p. 22).

\section{1. Linguistics}

Until the early years of the twentieth century, linguistic studies had largely beendominated by diachronic, or in other words, historical methods. Saussure, on the other hand, aimed at incorporating synchronicapproaches into the study of language and providing linguistics with a more scientific basis. Synchronic study works on the principle that language is a systematic organization and relationships between its constituents are to be examined without being affected by its historical development. Conversely, diachronic study focuses on genealogical evolution of language. French musicologist and ethnomusicologist Jean-Jacques Nattiez offers the following illustrationto elucidate the distinction betweendiachronic and synchronic approaches:

By diachronic is meant the study of the evolution of the language: how the Latin pater gives the French pére (father) for instance. A synchronic study, on the other hand, considers the same word, pére, in relation to other words of the same language at the same period (1973, p.55).

Saussure (2006) employs a chess metaphor to emphasize the study of language synchronically as well as diachronically:

Just as in chess it would be absurd to ask what a queen, a pawn, a bishop or a knight would be, if considered outside the game of chess, so there is no sense, if language is really what is being considered, in seeking what each element is in itself. It is nothing other than a piece whose value depends on its opposition to others within certain conventions...

... To understand the transformation of the various pieces with time, it is useful to analyse them in themselves (p. 44).

In the second place, the distinction between twoSaussureanlinguistics terms langue andparoleis an important portion of structural linguistics theory. Langue suggestsawhole system consisting of signs and sounds used for communication purposes. That is, langue is the crucial concept of which underlying structures to be examined synchronically. The way of examining these underlying structures, on the other hand, is made through parole, which indicates utterancesof individual, or in other words, the use of language. Alastair Williams (2001) draws an analogy between the functions of langue and parole, 
and theory and analysis. Apart from langue and parole, anotherdivision made by Saussure (2006) is the concept of langage. In his words:

Language (langage) is a phenomenon; it is the exercise of a human faculty. The language system (langue) is the interlocking set of forms that the language faculty assumes among a group of individuals at any particular time (p. 85).

Taken all together, what Saussure mainly intended to discuss was how linguistics was essentially a signifying system which is a component of a greater whole-semiotics. The postulation ofthe sign, composed of signifier and signified, as the fundamental unit of the language was one of the most pathbreaking facets of structural linguistics. Signifier, a sound-image, is the way ofindicating an entity as a sound or symbol. Put another way, it is the written and verbal condition of a concept or object. Signified, on the other hand, is the referent, the concept to which the signifier refers. Significantly, the connection between signifier and signified is completely arbitrary andthey are not necessarily connected to each other in a logical manner. Nevertheless, every single signified is designated with a particular signifier and the meaning is entirely differentiated by a small difference in signifier. One's mind recognizes a sign and reachesits meaning not because it has a unique position in the system but because it is different from all other signifiers. This argument provided Saussure with the basis for envisioning language as a system of differences. Susana Onega herself says, referring to and quoting Saussure, that "language is a system of differences that generates meaning through its own internal mechanisms" (2006, p. 262).

The great influence of Saussure's Course in General Linguistics was felt among many European, American and Russian linguists throughout the second quarter of the twentieth century. The Moscow Linguistic Circle founded by Czech linguist Roman Jakobson produced new studies by employing structuralist approaches and formed the vital part of the Russian formalism. Leonard Bloomfield, main founder of the Linguistic Society of America, was the leading figure for the development of structural linguistics in the United States.

Copenhagen School of linguistics is another notable center in Europe whose principles were built upon Saussure's structuralist approaches. Two prominent linguists, Louis Hjelmslev and Hans-JørgenUldall, express his gratitude to Saussure as developing glossematics(glossematik), a new approach to study of language. These abovementioned schools epitomize the Saussure's main aim for systematic investigation of language and the study of linguistics on a scientific basis.

The most prominent center among these linguistic schools, however, was the Prague School, formerly Prague Linguistic Circle, of linguistics. The study of the sound system of a given language or languages, which later turned into a subfield of linguistics called "phonology", emerged from Prague School. Phonology broke traditional method of determining the sounds in a specific language and inquired into the operating system of sounds and the relationships 
between them. Prague School scholars sought to analyzethe smallest units of sounds that change the whole meaning, or in other words, phonemes.A phoneme is significant sound contrasts that make differences between words and create completely different meaning. Taken a familiar example, in English $/ \mathrm{b} /$ and $/ \mathrm{v} /$ make difference and create different meaning such as ban and van. However, these sounds do not make any difference in Spanish. Native speakers of Spanish generally vocalize /b/ sound for both /b/ and /v/.

Studies on phonemics of Roman Jakobson, being the key figure of the school, and Nikolai Trubetzkoyhad a huge amount of influence on many other scholars from different fields to employ structuralist approaches based upon linguistic models. To sum up, phonemics was inspired from Saussure's structural theories and it encouraged further structuralist studies based on one of the principles of structuralism-meaning occurs through difference. As Jonathan Culler states, "structuralists have generally followed Jakobson and taken the binary opposition as a fundamental operation of the human mind basic to the production of meaning" $(1975$, p.15). Onega sums these contributions up in the followingmannerand takes the study to the next field hit by structuralism:

Jakobson's exposition, and modifications of Saussure's theory of langue as an oppositional system triggered Lévi-Strauss's decision to draw an analogy between kinship systems and language, both of which he subsumed under the category of 'communication' (2006, p. 262).

\section{2. Anthropology}

Anthropological studies share almost the same background with linguistics in terms of focusing on more scientific basis. Developments beginning from the early nineteenth century mark anthropology's attempts to distinguish itself as a scientific field. First, evolutionary principles were employed and anthropologists believed that cultures were hierarchically structured and they eventually evolved to a particular form. Second, Franz Boas, Alfred Reginald Radcliffe-Brown and Bronisław Malinowski and their functionalist approaches appeared as a reaction to evolutionary principles in the late nineteenth and early twentieth centuries.

Franz Boas, considered the principal figure of modern anthropology, was the first anthropologist to suspect the objectivity of Eurocentric fieldwork and observation. Boas, as a cultural relativist, criticized cultural evolution and observed each culture in terms of its inherent historical development and eschewed constructing generalizations applicable to all cultures. RadcliffeBrown, who developed the theory of structural functionalism, was deeply influenced by Émile Durkheim and his idea of social solidarity-the motivation that makes individual work with others-and claimed that group activities such as rituals and customs, take an important role to keep individuals acting as groupsand this is why function is strongly connected to social structure (Stone, 2008). Radcliffe-Brown rejected Malinowski's functionalism and asserted that 
social practices could not be explained only by individual's biological needs but also by the needs of groups.

Claude Lévi-Strauss, the father of structuralism, is the main figure as the originator of the structuralist philosophy in anthropology. Lévi-Straussnot only applied theories of structuralist approaches of linguistics to anthropology and provided a new method to explain the human society and culture but alsohe had a profound influence on many scholars from various fields outside anthropology primarily philosophy and literary studies. He proved the practicability of Saussure's structural principles beyond linguistics.

As stated earlier, his acquaintance withJakobson and his theories on structural linguistics played an important role for Lévi-Strauss informalizing his initial thoughts of Structural Anthropology. He first dug deeper into Saussure's premises on underlying structures of linguistic signs such as langue-paroleand signifier-signified (concepts discussed earlier) of which he later took advantage in his search for the basic mental structures of the human mind. Prague linguists and Jakobson's phonemics studies inspired him to extend these principles to examination of non-linguistic material primarily culture and other social sciences. According to Lévi-Strauss and the structuralist paradigm in anthropology, human thought and mind, suggested by the synchronic principles, functionsin the same way in all cultures no matter what the geographical or social conditions are. In addition, this universaloperation system of human mind is based upon binary oppositions such as male-female, dark-light, hot-cold and so forth. Structuralism focuses not on the elements of human mind, but rather on how it functions and relationships between its comprising elements. Structural anthropologists insist that underlying meaning of human mind can be understood by exploring underneath structures of cultural behavior shaped up by rituals, myths, kinship, institutions and so forth. It has been suggested that, Lévi-Strauss's thought about form bears a resemblance to that of Aristotle insofar as it is nothing more than the shape of contents in a given state of a systemand contents are not determined and developed by the form itself(Maranda, 1972). Karl's following words draw attention with its pertinence to this subject:

For the structuralists, then, the meaning of any particular unit is determined primarily by its relation to other units in a system and not by its intrinsic characteristics. Second is the tendency to use a binary model in analyzing the relations among phenomena in a system (Karl, 1997, p. 17).

One of the secrets of human mind, according to Lévi-Strauss, is hidden behind myths and deciphering the fundamental organization of myths is equivalent for revelationof human mind and its operation system.In addition to his search for decoding mythological organization, Lévi-Strauss focused on various cultural practices such as kinship, language, food preparation, games and others.The following statement of Kurzweil(1980) offers an idea about Lévi-Strauss's method of analysis of a given myth: 
First, he had to break down each myth into short sentences and to catalog them; each of these short sentences (constituent units) could produce a functional meaning only when it was combined with other such units into "bundles of relations" that would account for the two-dimensional time referent, revertible and non revertible time, and would constitute the primary elements of myths. He then proceeded to unravel a myth as if it were an orchestra score, to read it in three-dimensional fashion, so that, for instance, a series of "constituent units" such as $1,2,4,7,8,2,3,4,6,8,1,4,5,7,8$, might be analyzed according to the scheme:

\section{8}

$$
\begin{array}{lrll}
234 & 6 & 8 \\
1 & 45 & 78 \text { (p. 15) }
\end{array}
$$

Another point that deserves attention regarding Lévi-Strauss and his structural analysis of myth repertoires is particularly pertinent to the present context. LéviStrauss believed that music had a special relationship with myth andhe madethorough comparisons between myth and musicin Le Cru et le Cuit (The Raw and the Cooked). Furthermore, with the collaboration of French composer, conductor and theorist René Leibowitz, he provideda structural analysis of Ravel's Boléroin the "Finale" of L'homme nu(The Naked Man).

Pandora Hopkins summarizes the observations of Lévi-Strauss's myth and music comparison by suggesting that both music and myth are basically structural in terms of being untranslatable; second, the component parts of each are infinitely convertible and both of them comprise of a basic dichotomy which is theme and countertheme; and third, each can be inverted, rhythmically distorted, modally transformed, or presented in a new timbre (1977). Hopkins (1977) then goes on to discuss the comparison in the following manner:

Further, both music and myth are coded schemes (music, of sounds, and myth, of images) that are culturally determined (and vary from society to society) but have what he refers to as an "external level" (a physiological dimension, in the case of music, and historical facts or "supposed facts," in the case of myth) (p. 250).

Lévi-Strauss's original words stressthe importance of music as a cultural actin a passage in The Naked Man making a comparison between mythical and musical practice:

Mythology and music have in common the fact that they summon the listener to a concrete form of union, with the difference, however, that myth offers him a pattern coded in images instead of sounds. In both cases, however, it is the listener who puts one or several potential meanings into the pattern, with the result that the real unity of the myth or the musical work is achieved by two participants, in and through a kind of celebration (1981, p. 654).

\section{Musical Discourses in Structural Context}

The wave of structuralistideas in linguistics, anthropology and literary theory spread through the major territories of musicsuch as music theory and analysis, musicology and ethnomusicology in the twentieth century. Basic linguistic, anthropological, semiologicaland psychological theories and applications of 
mainstream structuralist figures of these disciplines were subjected to close scrutiny by numerous musical structuralists particularly after the second half of the twentieth century. Before the discussion of the structuralist journey of music, it might be useful to review the main destination of this insight:

The kindred approaches of semiology and structuralism both tend to reduce all kinds of non-linguistic social communication to the state of natural language, semiology by treating all the ways in which human beings signal to each other (by the clothes they wear, the gestures they make, the food they eat and so on) as 'codes' containing 'messages' which can be encoded and decoded by those familiar with that code, structuralism by seeing all social phenomena as 'wholes' (or 'structures') whose elements are governed by well-defined laws (Bent and Pople 2007).

In this respect, the following question, which had already been in minds since the early years of 1950s, reiterated by Gilbert Chase in his paper in 1972. "Can the musicologist, using a method analogous to the method used in structural linguistics, achieve the same kind of progress in his own science as that which has taken place in linguistics?" (1972, p. 127). On the one hand Chase raised this question, but on the other hand he previously evinced in the same paper that he was not much concerned with the answer bysuggesting anapproach for structuralist musicology and showing his enthusiasm for structuralism with these words:

It seems to me that musicologists would do well to approach structuralism by the high-road of general theory, with special attention to linguistics, rather than to seek an immediate by-path to music (1972, p. 122).

The rest of the present paper will not intend to give an answer to Chase's question either. Rather it will simply attempt to give an idea about structuralist approaches in music and evolution of structuralist context in musical discourses.

\section{1. Musicology and Music Theory and Analysis}

The transformation of linguistics into a scientific field at turn of the twentieth century began to influence musicology and musical theory and analysis in the 1930s and 1940s and culminated in the 1950s and 1960s with the increasing number of works in connection with structuralism and semantics. In this context, Nicolas Ruwet and Jean-Jacques Nattiez are the two remarkable scholars whose works provided very important contributions for the development of structuralist ideas in musical analysis.

Ruwet, the senior of Nattiez, is originally alinguistwho had the opportunity of being taught by many significant figures affiliated with structuralist linessuch as Lévi-Strauss, Jakobson and Noam Chomsky. Having study music privately, he has incorporated hiswell-built linguistic background into music analysis and provided invaluable works for the semiotics of music. As Nattiez suggests, "the articles that this author (Nicolas Ruwet) has written seem to us to point the most substantial direction for musical semiology to take in the future" (1973, p. 55). Ruwet acknowledges the teachings of Belgian composer and writer André 
Souris and Pierre Froidebise for his musical training and for the development of his methods (Ruwet and Everist 1987). His most remarkable series of articles Méthodesd'analyseenMusicologie (Methods of Analysis in Musicology) and some of his musical analysis, mostly focused onmonodies from the twelfth to fourteenth centuries, were published in Langage, Musique, Poésie(Language, Music, Poetics) in 1972.

Ruwetdeveloped a new method of musical analysis that later called paradigmatic analysis. Similar to Lévi-Strauss's method of analysis of myths, Ruwet, according to his method of paradigmatic analysis, analyzed a piece of music by breaking the entire composition down into small parts based on the idea of repetition (See Figure 1). Then he cataloged these parts and analyzed relationships of these smaller parts both with each other and with the whole. Williams proposes that paradigmatic analysis technique "segments the diachronic process of the music into synchronic columns of equivalent events. It then searches for rules of identity and transformation between the isolated events" (Williams 2001: 26). Mark Everistcomments on Ruwet's contribution:

There will be many objections to the viewpoint proposed in 'Methods'. Certainly the emphasis on modal categorization misses its target. But it is equally true that many of the suggestions explicitly offered by Ruwet (the investigation of parametric/non-parametric elements) and Vaccaro (the application of this approach to other repertories), as well as those which have so far only been hinted at (comparative studies and the theoretical evaluation of empiricism and pragmatism in the context of this analytical method) have yet to be taken up (1987, p. 7).

Ruwet'ssegmentational analysis of the Geisslerlied inspired numerous scholars to inquire deeply into music and its analysis. Jean-Jacques Nattiez, the student of Nicolas Ruwet, is a remarkable figure who prolifically works for integrating the premises of semiotics into musical analysis. The following words demonstrate his strict adherence to music and linguistic models of structuralism:

... music is perhaps the non-linguistic field where linguistic models can most successfully be applied, which is surprising when one considers that music is one of the last fields towards which linguistics has reached out, after the structures of kinship, myth, fashion, the unconscious, and biological, literary and cinematic structure (Nattiez, 1973, p. 52).

Nattiezmade great contributions to musical semiotics. He edited the fifth volume of periodical Musiqueenjeu published in 1971 of which the issue devoted to "Semiologie de la Musique". The issue republished the relevant papers of Roman Jakobson "Musikwissenschaft und Linguistik" published in 1932, George P. Springer "Language and Music: Parallels and Divergencies" published in 1956, Bruno Nettl "Some Linguistic Approaches to Musical Analysis" published in 1958, William Bright "Language and Music: Areas for Cooperation" published in 1963 and Roland Harweg "Sprache und Musik" published 1967. Nattiez published his first book-of which the revised version was published under the title Musicologiegénéraleetsémiologie in 1987-on the 
foundations of musical semiology (Fondementsd'unesémiologie de la musique)in 1975. In 1981, Nattiezbegan to co-edit the prestigious series Musique/Passé/Présentwith Pierre Boulez. He publishedhis other book Tétralogies 'Wagner, Boulez, Chéreau,' essai sur l'infidélité, in 1983, mainly focused on Wagner's music.

Nattiez shared Ruwet's thoughts and methods as far as making objective analyses and avoiding deductive reasoning concerned. Whittall states, quoting Nattiez (Musicologiegénéraleetsémiologie), that "For Nattiez, a composition is not merely 'a whole composed of "structures". . . . Rather, the work is also constituted by the procedures that have engendered it (acts of composition), and the procedures to which it gives rise: acts of interpretation and perception'" (Nattiez 1987, as cited by Whittall, 2001).Nattiez contends that musical activity is divided into three components (tripartitional). Nattiez used the semantic term "poietic", which means the productive levels of symbolic forms, to describe the first phase-the process of composition. "Neutral", the second part the musical activity, is the materialized product of the creation process. The third, "esthesic", is the perceptive level, the reaction of the listener. Nattiez method of analysis focuses on the "neutral" level and excludes compositional intention or reception history from its territory (Williams, 2001).

"a symbolic form ... is not some "intermediary" in a process of "communication" that transmits the meaning intended by the author to the audience; it is instead the result of a complex process of creation (the poietic process) that has to do with the form as well as the content of the work; it is also the point of departure for a complex process of reception (the esthesic process) that reconstructs a "message"(Nattiez, 1990, p. 17).

The tripartitional approach attempts to provide a scientific analysis of music. Like the Ruwet's paradigmatic analysis strategy, Nattiez's method endeavor to break the whole score into small unitsand to explore the structures and their relationships. The further process of the technique is summarized as follows:

Recurrent events are identified as belonging to a paradigm, to be tabulated on a vertical axis, while contiguous events appear horizontally, to form the axis of the syntagm. Internal relationships only are of concern. Each segmentational unit is a 'sign', held in relation to other 'signs', without regard to such things as effective connotation or cultural reference. (Cumming, 2007)

Having influenced byRuwet's method, Nattiez attempted to broaden the scope of musical analysis beyond early music. Ruwet'sGeisslerlied can be traced in his analysis of Debussy's Syrinx. It has been suggested that Nattiez analyzed on the basis of the shortest repeated time units instead of taking the longest repeated units first (Dunsby, 1983). Even though Williams (2001) criticizes the elimination of poietic and esthesic since "it suggests that music and analytical methodology can ... be removed from the discourses in which they are embedded" (p. 26).Nattiez presents both his viewpoint about what structural analysis aims for and his justification for the neutral method: 
The structural description of a musical text does not reveal a structure which was hidden in the text: it results from an abstract construction which is set up by the scholar but which, by virtue of its explicit and formalized character, other scholars can criticise and supersede. It is not therefore a matter of knowing whether the "revealed" structure corresponds to some conscious intention of the author: it is a model of the object which may be proved to be a misrepresentation. (1973, p. 64)

Apart from the emergence of preceding works developedby the influences of linguistic structuralism originated by Saussure, another chain of methodological assumptions that shares the parallel structural preoccupationswith Saussure's structuralism developed at turn of the twentieth century. In this regard, in order to discuss the further contributions to structuralist theory and analysis in music, it is necessary to refer briefly tothe Austrian theorist Heinrich Schenker whose teachings and thoughts have remained influential throughout the second half of the twentieth century.

Schenker's analysis technique departed from the purpose of understanding the creativity process of composers. Schenker inquired mainly into setting out the structure ofeighteenth and nineteenth century's tonal masterpieces of European music and their analysis of musical cognition. It is crucialto emphasize that the cognition,which is in question,is confined to those of expert composers, musicians and listeners. Schenkerian analysis is concerned neither about authorial intention nor about historical detail but instead it focuses on internal structure and deep-rooted properties of tonality (Williams, 2001).

Schenker was the first theorist to disregard the formal construction of the music (sonata, binary, rondo, canon, etc.).Rather he attempts to describe the structure by means of defining hierarchical relationships among contrapuntal, harmonic, and melodic elements by reducing the music to anarhythmicfundamental structure-Ursatz.Snarrenberg (2001) states that "To the extent that it is a theory of how mental prototypes shape musical perception, his theory is consistent in its approach with the most recent advances in the understanding of perception".

Schenker's analytical method developed in the course of time and the formation of the method can be traced within his three-volume treatiseNeueMusikalischeTheorien und Phantasien (New Musical Theories and Fantasies).The first Harmonielehre (Harmony) and the second volume Kontrapunkt (Counterpoint) were published respectively in 1906 and 1910. The third volume DerFreieSatz (Free Composition) was published posthumously in 1935.

Schenkerian analysis is basically comprised of three hierarchically organized structural levels. Foreground, the surface level, is the immanent musical composition, that is to say, the final version of a given piece after theProlongational or middlegroundlevel, the transformational stage-where the decorative elements are inserted-of background level, or in other words, the deep,long-range fundamental structure reduced to atwo-voice structure which does not have a particular rhythm. Even though the method aims to distinguish 
these three levels in aparticular music and arrive at the ursatz, it acknowledges the relationship among three levels and does not ignore the foreground and middleground levels completely. As Whittall(2001) suggests, "it would be wrong to argue that the Schenkerian analytical process consists of progressively discarding all the various decorative, motivic, and other less vital structural elements until the music is reduced to its abstract, unrhythmicUrsatz".To quote Whittall againfor a general view:

It is Schenker's concern with the organic integration generated from a deep structure which made him the supreme advocate of a classic style of composition, in which contrast and diversity are not merely subordinate to unifying forces but are generated by the spatial and temporal evolution of those forces (2001).

Felix Salzer, one of the disciplesof Schenker, is an important musicologist and music theorist who made significant contributions to the dissemination of Schenkerian approaches particularly in the United States to which he immigrated in 1940. Furthermore, not only did he maintain and present Schenker's ideas tothe interest of numerous musicologists and theorist but also he provided Schenker's analysis technique to be applied to a wider range in tonal music analysisfrom the Middle Ages to twentieth century.

Having largely influenced by Schenker, Salzer published his first book Structural Hearing, a pedagogical work, in 1952 with the purpose of helping musicians to acquire structural hearing ability and as well as providing a composition method and analysis. Salzer's book, which includes Schenker'sideas and his musical analysis technique, turned into an important source of Schenkerian analysis and retained this position for a long time since there was no English translation of Schenker's writings (The English translation of Schenker'sDerFreieSatzwas not published until 1979).Apart from widening the application of Schenkerian theories from fourteenth century to twentieth century, Salzerexhibited many original ideas for the development of these principles in Structural Hearing.

First, Structural Hearingsuggests the concept of musicalcomposition as a totality, a hierarchical organization instead of a series of events and the relationships between these events. One of the most important concepts developed by Salzer is the "prolongation".Prolongationis the harmonic and contrapuntal details of a musical composition generated by linear elaboration of the background structure. This view enables an analytical method in which every single musical movement evaluated by its relationship to the whole structure rather than analyzing the series of events, or in other words, relationships between adjacent pitches and chords. Salzer(1952) himself states that ". . . any chord whatsoever, be it consonant or dissonant, diatonic or chromatic may appear within any given tonal framework. The sole deciding factor justifying its presence is whether its function within the framework is clearly defined as an integral part of the whole" (p. 227). 
Salzer's second workCounterpoint in Composition: The Study of Voice Leading, co-authored with Carl Schachter, published in 1965.This work mainly intended to "emphasize the relationship of (Johann Joseph)Fux's principles of species counterpoint to tonal music of all styles, thus extending the concepts of partwriting evolved in Schenker's later writings" (Novack, 2001).

Allen Forte is another important music theorist and musicologist who has produced powerful works in structuralist path by expandingSchenker's theories. Forte published a number of booksContemporary Tone-Structures(1955),The Compositional Matrix (1961), Tonal Harmony in Concept and Practice(1962),The Structure of Atonal Music (1973), The Harmonic Organization of the Rite of Spring(1978) and The Atonal Music of Anton Webern (1997). In addition, he has enlarged his theories' range of application to the extent of atonal music analysis by incorporating computer technology into his analyses.

The Structure of Atonal Music, his most influential work,rises to the challenge for analyzing pre-serial atonal music. Attempting to apply Schenker's principles to post-tonal music analysis, Forte centered his work based upon mathematical set theory and discovered the "pitch-class set theory" thataims at establishing classified sets by reducing the close pitches- the concept of octave is neglected and all enharmonically equivalent pitches are considered equal-of whole notation to relative segmentations. This approach is defined in terms of its affinity with structuralism:

With its firm belief that surface phenomena are governed by underlying patterns, set theory is resolutely structuralist, and has been widely criticized for performing clinical autopsies on living organisms. Just as the structuralist analysis of myth turns away from narrative flow, so pitch-class analysis abandons the temporal unfolding of the music and looks for underlying similarities and differences (Williams, 2001, p. 26).

There are many other respectable scholars-most remarkably Maury Yeston, Stephen Gilbert, Berry Wallace, Edward Cone, Eugene Narmour, David Epstein and Fred Lerdahl-who have provided structuralist approach with invaluable inputs either by following Schenker or Saussure's principles. However, the present study begs off from examining them one by one in order to survey the structuralist traces in the field of ethnomusicology.

\section{2. Ethnomusicology}

Because of two reasons, it would have hardly been surprising thatstructuralist ideashad been given the opportunity of admittance inthe field of ethnomusicology. First, the influence of Saussure's revolutionaryideas in linguistics was extremely powerful and music, which had always been close to language since both considereda communication system and had endeavoredto differentiate its studies from those of other sciences for a long time, was more than ready for its own revolution. In addition, the redefinitionof linguistics as a part of a larger science-semiology- has given rise to a closer relationship 
between two fields and having a natural bond with music, ethnomusicology has been included in this relationship.

Namely, language and music are the two principal ways by which humans pattern sound for social communication. For this reason it has been argued that language and music are both open to analyses of a general semiotic character, and, hence, that they may benefit from uniformities in analytic approach (Feld, 1974, p. 198)

Second, ethnomusicology, the study of social and cultural aspects of music, has also had a strong relationships with anthropology on which structuralism has made its strongest impact. However, not only does multidisciplinary nature of ethnomusicology invite structuralism but also it entails employing structuralist principles more strictly. Anthony Seeger (2004) clarifies the importance of structuralist approaches in ethnomusicological studies with a caveat that it should not ever be divorced from discovery procedures of ethnomusicology:

Any ethnomusicological study of music should begin by examining music in relationship to other art forms, because nothing simply exists in itself. Everything is always partly defined by what it is not - by the other members of a set which usually are systematically related among themselves. Definition through interrelationship is a fundamental tenet of structuralism and semiotics, and yet it is often ignored in ethnomusicological studies (p. 25).

To conclude this discussion, ethnomusicologists are given a reminder by Chase not to ignore the origins of structuralism. He states that "While ethnomusicologists, in particular, will naturally be interested in whatever pertains to structuralism and the social sciences, the fact remains that the main link between structuralism and musicology has been established through linguistics" (Chase, 1972, p. 126).

Linguistics, semiotics (could be considered along with linguistics) and paradigmatic analysis models are three strands of the development of structuralism in ethnomusicology. Although several writings and applications began to appear in the late 1950s and early 1960s, the most prolific and thorough structuralist works became prevalent in the early 1970s. Steven Feld points out:

The current growth of the .... idea (Applying linguistic models to musical analysis), has, no doubt, been spurned by the use of structural linguistic models in anthropology and folklore (Levi-Strauss 1963), the development of transformational linguistics (Chomsky 1957, 1965), and the new popularity of semiotics (Morris 1938) (1974, p. 197).

One of the most significant ethnomusicologists who thoroughlyemployedthe principles of both structural anthropology and linguistics is the British ethnomusicologist and anthropologist John Blacking. He developed his method of "Cultural Analysis" based upon the presupposition that no matter to what culture, composer or genre a music belongs, it could be described by a unitary methodwhich aims at explaining both the musical and cultural background and structuralism could be the fundamental method for thissystem of analysis 
(Chase, 1972).The insight of John Blacking creates a general idea about ethnomusicological interpretation of structuralism. In addition, Steven Feld's "Linguistic Models in Ethnomusicology", from which the current paper has quoted several times, provides a significant source for a wide-ranging evaluation and analysis of numerous structuralist attempts that had been made until 1974. Another work of Feld, published in 1982, "Sound and Sentiment: Birds, Weeping, Poetics, and Song in Kaluli Expression", bears many similarities to Lévi-Strauss's structural analysis of myth. Feld provides many helpful comparisons between the structures of myth and structures of music (Stone, 2008). As a young and multidisciplinary field, ethnomusicology is expected to employ new methodologies influenced or inspired by structuralist ideas.

\section{Summary and Conclusion}

This rapid survey has presented an overview of the foundations and development of one of the most debatable and elusiveconcepts of the twentieth century and its position within linguistics, anthropology and music by examiningmajor contributions in each field and tracing its differentiationwithin the perception of each theorist and intellectual. Structuralist approaches in linguistics, anthropology has been particularly included for the purpose of supporting reader's outlook on musical discourse.

In conclusion, I should like to say that a number of areas have received the influences of structuralistthinking and it is a fortunate that music and its main branches have been one of these areas. Even though there have beena few negative criticisms, which have not been included in the context, as well as numerous approval and praise, any musical work and its analysis either its cultural or musical context would be considered incomplete without the consideration of structuralist approaches in the presence of myriads of profound studies.

\section{References}

Bent, I. D. andPople, A. (2001). "Analysis." Grove Music Online. http://www.oxfordmusiconline.com

Blacking, J. (1971).Deep and Surface Structures in Venda Music. Yearbook of the International Folk Music Council, 3, 91-108.

Chase, G. (1972). Editor's Outlook: Structuralism, Linguistics, and Musicology. AnuarioInteramericano de Investigacion Musical 8: 121-131.

Culler, J. D. (1975). Structuralist Poetics: Structuralism, Linguistics and the Study of Literature. London: Routledge and Kegan Paul.

Cumming, N. (2001). "Semiotics." Grove Music Online. http://www.oxfordmusiconline.com

Dunsby, J. (1983).Music and Semiotics: The Nattiez Phase. The Musical Quarterly,69 (1), 27-43. 
Feld, S. (1974). "Linguistic Models in Ethnomusicology." Ethnomusicology 18(2), 197-217.

Gardner, H. (1973). The Quest for Mind. New York: Knopf.

Hopkins, P. (1977). The Homology of Music and Myth: Views of Lévi-Strauss on Musical Structure. Ethnomusicology 21(2): 247-261.

Karl, G. (1997). Structuralism and Musical Plot. Music Theory Spectrum 19 (1), 13-34. University of California Press on behalf of the Society for Music Theory.

Kurzweil, E. (1980). The Age of Structuralism: Lévi-Strauss to Foucault. New York: Columbia University Press.

Lane, M.(1970 ). Structuralism: A reader. London: Jonathan Cape.

Lévi-Strauss, C. (1981). The Naked Man, Introduction to a Science of Mythology: 4. Translated by John and Doreen Wightman. New York: Harper and Row.

--------(1963). Structural Anthropology. Translated from the French by Claire Jacobson and Brooke GrundfestSchoepf. New York, London: Basic Books, Inc.

Maranda, P. (1972). Structuralism in Cultural Anthropology. Annual Review of Anthropology 1, 329-348.

Nattiez, J-J. (1973). Linguistics: A New Approach for Musical Analysis?.International Review of the Aesthetics and Sociology of Music 4 (1), 51-68.

--(1990). Music and Discourse: Toward a Semiology of Music. Translated by Carolyn Abbate. Princeton, N.J.: Princeton University Press.

Novack, S. (2001). "Salzer, Felix"Grove Music Online. http://www.oxfordmusiconline.com

Onega, S. (2006). Structuralism and Narrative Poetics. Patricia Waugh(Ed.).An Oxford Guide: Literary Theory and Criticism(pp. 259-79). New York: Oxford University Press

Ruwet N. and Everist M. (1987). "Methods of Analysis in Musicology." Music Analysis 6(1/2): 3-36.

Salzer, F. (1952). Structural Hearing: Tonal Coherence in Music. 2 Vols. New York: Charles Boni.

Saussure, F. de. (2006). Writings in General Linguistics. Trans. Carol Sanders, Matthew Pires, Peter Figueroa). London; New York: Oxford University Press. 
Hongur, G. (2017).Structuralist Paradigm and Music. Humanitas, 5(9), 155-171

Seeger, A. (2004). Why Suyá Sing: A Musical Anthropology of an Amazonian People. Urbana and Chicago: University of Illinois Press.

Stone, R. M. (2008). Theory for Ethnomusicology. Upper Saddle River, NJ: Pearson Prentice Hall.

Snarrenberg, R. (2001). "Schenker, Heinrich"Grove Music Online. http://www.oxfordmusiconline.com

Whittall, A. (2001). "Form."Grove Music Online. http://www.oxfordmusiconline.com

Williams, A. (2001). Constructing Musicology. Aldershot: Ashgate. 